\title{
Studi Potensi Air Tanah Untuk Penanggulangan Krisis Air Baku Di Kabupaten Gunung Mas
}

\author{
Hendra Wahyudi * \\ Departemen Teknik Infrastruktur Sipil, ITS, Surabaya \\ Koresponden*, Email: ayahkukung@gmail.com
}

\begin{tabular}{ll}
\hline \multicolumn{1}{c}{ Info Artikel } & Abstract \\
\hline Diajukan 23 November 2017 & Gunung Mas District in Central Kalimantan Province is the result of expansion of The Kapuas \\
Diperbaiki 05 Desember 2017 & District based on Undang-undang No 5 tahun 2002, has an area of 10,804 km2. Gunung Mas \\
Disetujui 28 Pebruari 2018 & District's topography can be, named the northern part of the hill while the south is a flat area \\
& and swamp that passed four rivers. Gunung Mas District has huge mining potential but it is \\
& still managed traditionally, it causes pollution that destroys the environment. This study looks \\
& at the potential of groundwater present in Gunung Mas district to overcome the problem of \\
& water shortage by conducting a geoelectric investigation. Based on geoelectric mapping \\
& conducted in Gunung Mas District on Tanjung Riu has a potential of 3.27 l/sec, Petak \\
& Bahandang has a potential of 0.605 l/sec, Tumbang Lake has a potential of 1,175 l/sec, \\
& Kampuri has potential of 4.571 l/sec, Tewai baru has a potential of 5.821 l/sec, while Sepang \\
Keywords: Gunung Mas District, Clean & Kota has a potential of 4,661 l/sec.
\end{tabular}

Abstrak

Kabupaten Gunung Mas Propinsi Kalimantan Tengah merupakan hasil pemekaran dari Kabupaten Kapuas berdasarkan Undang undang nomor 5 tahun 2002 memiliki luas wilayah $10.804 \mathrm{Km}^{2}$. Kabupaten Gunung Mas ini mempunyai topografi bagian Utara berupa perbukitan sedangkan sebelah selatan berupa daerah datar dan rawa yang dilewati empat sungai. Kabupaten Gunung Mas mempunyai potensi tambang yang sangat besar namun masih dikelola secara tradisonal sehingga menimbulkan pencemaran yang merusak lingkungan. Studi ini melihat potensi air tanah yang ada di Kabupaten Gunung Mas untuk mengatasi masalah kekurangan air bersih dengan melakukan penyelidikan geolistrik. Berdasarkan pemetaan geolistrik yang dilakukan di Kabupaten Gunung Mas pada daerah Tanjung Riu mempunyai potensi 3.27 1/dt, Petak Bahandang mempunyai potensi sebesar 0.605 l/dt, Tumbang Danau mempunyai potensi sebesar 1.175 l/dt, Kampuri mempunyai potensi sebesar $4.571 \mathrm{l} / \mathrm{dt}$, Tewai Baru mempunyai potensi sebesar 5,821 l/dt, sedangkan

Kata kunci: Kabupaten Gunung Mas, Air Bersih, Potensi Air Tanah, Geolistrik.

\section{Latar Belakang}

Kabupaten Gunung Mas Propinsi Kalimantan Tengah merupakan hasil pemekaran dari Kabupaten Kapuas berdasarkan Undang undang nomor 5 tahun 2002 terletak antara $0^{\circ} 18^{\prime \prime} 00$ Lintang Selatan sampai dengan $01^{\circ} 40$ ' 30" Lintang Selatan dan $113^{\circ} 01$ ' 00" Bujur Timur sampai dengan $114^{0} 01$ ' 00" Bujur Timur, memiliki luas wilayah $10.804 \mathrm{Km}^{2}$.

Kabupaten Gunung Mas ini mempunyai topografi yang secara garis besar dapat dibagi dua bagian yaitu sebelah Utara yang merupakan daerah perbukitan dengan ketinggian antara 100 sampai dengan 500 meter dari permukaan laut dengan puncaknya di pegunungan Muller dan pegunungan Schwanner dengan tertinggi mencapai 2.278 meter dari permukaan laut sedangkan bagian Selatan merupakan dataran rendah dan rawa serta dilewati empat sungai Manuhing dengan panjang $28.75 \mathrm{~km}$, sungai Rungan dengan panjang $86.25 \mathrm{~km}$, sungai Kahayan dengan panjang $600 \mathrm{~km}$ dan sungai Miri.

Potensi tambang yang ada di Kabupaten Gunung Mas sangat besar namun masih belum dikelola secara tradisonal sehingga sangat merusak lingkungan karena menggunakan bahan yang berbahaya misalnya air raksa untuk memisahkan emas dengan tanah yang ada. Sehingga potensi air yang ada ada di Kabupaten Gunung Mas dengan dilewati empat sungai tersebut secara kuantitas melimpah namun secara kualitas sangat jelek karena warnanya coklat cenderung kemerahan akibat pirit dan kualitasnya jelek karena terkontaminasi material tambang sehingga menyebabkan kekurangan air baku, sehingga perlu dicarikan sumber air baku selain dari empat sungai tersebut. Penelitian tentang studi potensi air tanah untuk penanggulangan krisis air baku di Kabupaten Gunung Mas, berdasarkan latar belakang yang sudah dipaparkan diatas maka ada beberapa permasalahan yang 
dapat dirumuskan sebagai berikut ini yaitu diduga daerah di Kabupaten Gunung Mas mempunyai potensi air tanah yang dapat dimanfaatkan untuk menanggulangi krisis air baku. Dan diduga metode geolistrik dapat dipergunakan untuk memprediksi lokasi aquifer sedangkan aquifer merupakan daerah yang mampu menyimpan air sehingga metode geolistrik dapat digunakan untuk mengetahui potensi air tanah.

Penelitian geolistrik ini hanya dilakukan pada Daerah Tanjung Riu, Petak Bahandang, Tumbang Danau, Kampuri, Tewai Baru sampai Sepang Kota seperti terlihat pada Gambar 1.

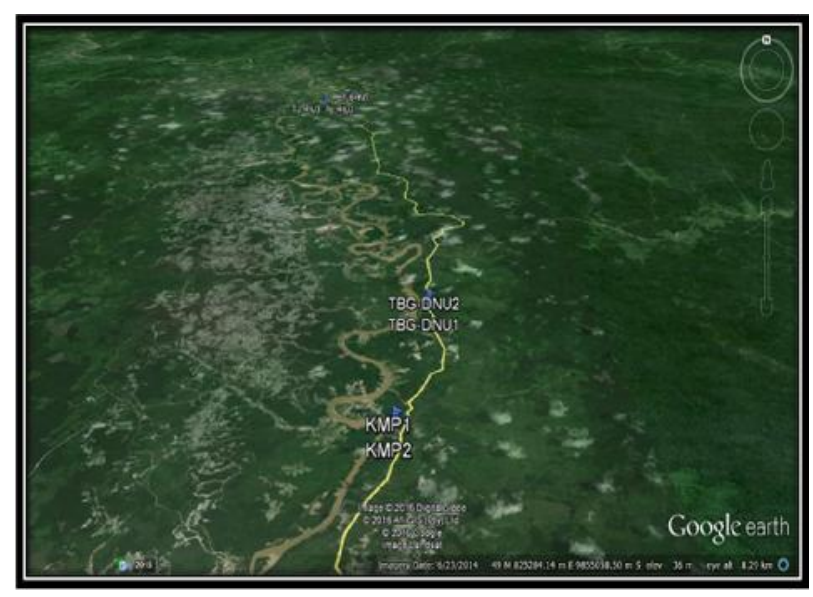

Gambar 1. Lokasi letak Geolistrik di Kabupaten Gunung Mas

\section{Metode}

Bumi diasumsikan mempunyai sifat homogen isotropis (terdiri dari satu lapis) sehingga hambatan jenis yang terukur adalah hambatan jenis yang sesungguhnya dan tidak tergantung pada spasi elektroda. Namun kenyataannya bumi terdiri atas lapisan-lapisan yang mempunyai hambatan jenis yang berbeda sehingga potensial yang terukur merupakan pengaruh dari lapisan-lapisan tersebut. Harga hambatan jenis yang terukur bukan merupakan harga hambatan jenis untuk satu lapisan saja, kondisi ini terutama karena spasi elektroda yang lebar:

$\rho_{a}=\frac{K \cdot \Delta V}{I}$

Dalam hal ini, $\rho_{a}$ adalah hambatan jenis semu (Apparent Resistivity) yang tergantung pada spasi elektroda. Harga resistivitas untuk berbagai jenis batuan dapat dilihat pada tabel 1, dan tabel 2.
Tabel 1. Nilai Resistivitas Batuan

\begin{tabular}{lc}
\hline Material & Resistivitas (ohm meter) \\
\hline Sedimentary Rock & $10-10^{3}$ \\
Shale & $1-10^{9}$ \\
Sandstone & $50-10^{7}$ \\
Limestone & $10^{2}-10^{4}$ \\
Dolomite & $10^{2}-5.10^{4}$ \\
Lavas & $2.10^{1}-2.10^{2}$ \\
Tuffs & \\
Unconsolidated Sediment & $1-10^{3}$ \\
Sand & $1-10^{2}$ \\
Clay & $1-10^{2}$ \\
Marl & \\
Groundwater & $0.1-10^{3}$ \\
Portable well water & $0.2-1$ \\
Brackish water & 0.2 \\
Sea water & $0.5-0.2$ \\
Supersaline brine &
\end{tabular}

Sumber:Telford, $d k k[1]$

Tabel 2. Nilai Resistivitas Batuan

\begin{tabular}{lc}
\hline Jenis batuan & $\begin{array}{c}\text { Resistivitas } \\
\text { (ohm.meter) }\end{array}$ \\
\hline Gambut dan lempung & $8-50$ \\
Lempung pasiran dan lapisan & $40-250$ \\
Kerikil & $40-100$ \\
Pasir dan kerikil jenuh & $100-3000$ \\
Pasir dan kerikil kering & $8-100$ \\
Batu lempung, napal dan serpih & $100-4000$ \\
Batu pasir dan batu kapur (breksi) & \\
Sumber: Verhoef [2] &
\end{tabular}

Menurut Robinson dalam Hendra[3], interpretasi dari pengukuran geolistrik resistivitas didasarkan pada anggapananggapan sebagai bahwa bawah permukaan tanah terdiri dari beberapa lapisan yang dibatasi oleh bidang batas horisontal serta terdapat kontras resistivitas antara bidang batas per lapisan tersebut; Lapisan bumi bersifat homogen isotropik dan mempunyai ketebalan tertentu, kecuali untuk lapisan terbawah mempunyai ketebalan yang tidak terjangkau; Batas antara dua lapisan merupakan bidang batas antara dua resistivitas yang berbeda dan di dalam bumi tidak ada sumber listrik lain selain listrik searah (DC) yang diinjeksikan diatas permukaan bumi. Menurut tatas dkk, salah satu metode yang dapat digunakan untuk mengetahui struktur hidrogeologi adalah dengan menggunakan geolistrik[4].

Pengambilan data primer dengan melakukan pengukuran geolistrik mempergunakan konfigurasi Schlumberger. Adapun langkah pengukuran geolistrik dengan mempergunakan konfigurasi Schlumberger dapat dijelaskan sebagai berikut: 
- Elektrode luar dipasang luar pada jarak tertentu (AB) untuk mengalirkan arus DC dengan frekuensi rendah ke dalam tanah (orde arus adalah 20 sampai 75 mili amper dengan tegangan yang ada 100 dan $600 \mathrm{~V}$ ), sehingga diperoleh tegangan terukur yaitu keluaran dari elektrode dalam $(\mathrm{MN})$.

- Setiap jarak perubahan posisi dari masing-masing harus dicatat sehingga besar hambatan semu pada setiap kedalaman titik sounding dapat diukur sesuai capaian kedalaman yang diinginkan.

- Semakin lebar arus jarak elektrode maka kebutuhan kedalaman yang diperkirakan semakin dalam. Sebagai gambaran untuk kedalaman 150 meter, maka diperlukan paling tidak panjang lintasan 100 meter sampai $150 \mathrm{~m}$ untuk masing-masing sisi. Sehingga total panjang lintasan adalah 200 sampai $300 \mathrm{~m}$.

Untuk lebih jelasnya pemetaan geolistrik dengan konfigurasi Schlumberger dengan memakai 4 elektroda dapat dilihat pada gambar 2 .

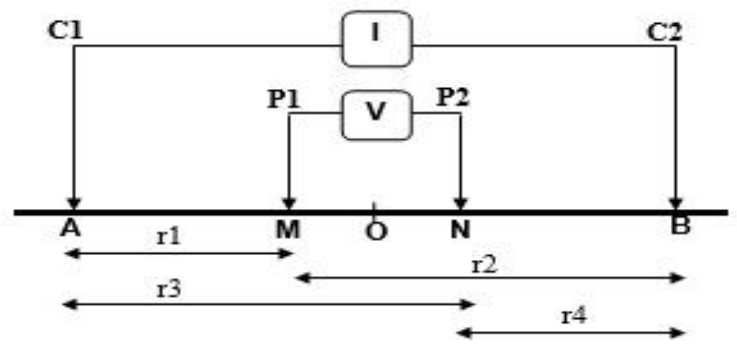

Gambar 2. Konfigurasi elektrode konfigurasi Schlumberger

\section{Hasil dan Pembahasan.}

Hasil pengambilan data geolistrik yang dilakukan di daerah Tanjung Riu dapat dilihat pada Gambar 3.

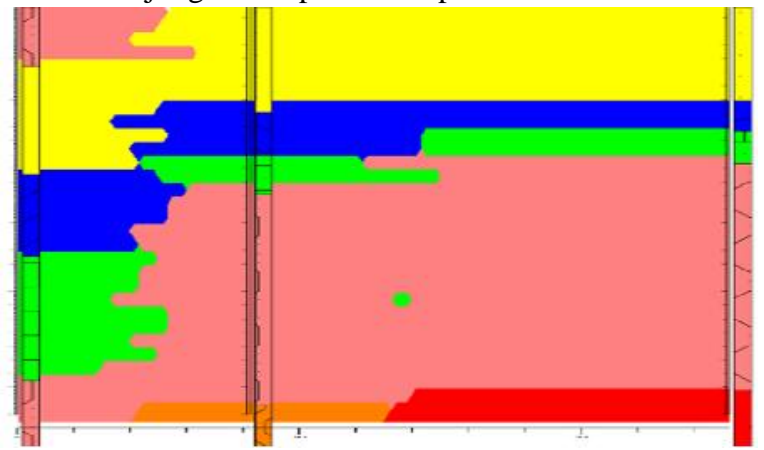

Gambar 3. Hasil Pengukuran Geolistrik di Daerah Tanjung Riu

Pembahasan hasil penyelidikan geolistrik seperti yang dapat dilihat pada Gambar 3 adalah bahwa pada Tanjung Riu 1 lapisan akuifer diidentifikasi pada 2 kedalaman, antara lain:
1. Kedalaman 22,79 sampai 62,40 meter; ketebalan lapisan 39,61 meter; nilai resistivitas batuan $108,82 \mathrm{~m}$; tipe akuifer tertekan dengan lapisan kedap bagian atas kerikil dan lapisan kedap bagian bawah lempung; transmisivitas $0,00550 \mathrm{~m}^{2} /$ det dan debit potensial 2,635 1/det.

2. Kedalaman 92,24 sampai 137,57 meter; ketebalan lapisan 45,33 meter; nilai resistivitas batuan $33,81 \mathrm{~m}$; tipe akuifer tertekan dengan lapisan kedap bagian atas kerikil dan lapisan kedap bagian bawah kerikil; transmisivitas $0.00131 \mathrm{~m}^{2} /$ det dan debit potensial $0,6281 /$ det.

Total debit potensial yang dimiliki oleh titik Tanjung Riu 1 sebesar 3,27 1/det. Hasil pengukuran geolistrik yang dilakukan di Daerah Petak Bahandang dapat dilihat pada Gambar 4.

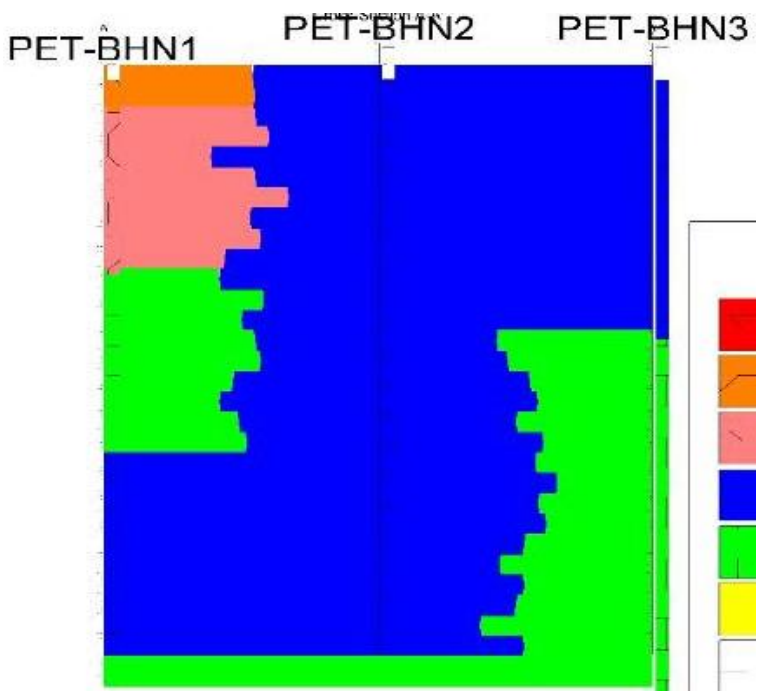

Gambar 4. Hasil Pengukuran Geolistrik di Daerah Petak Bahandang

Pembahasan hasil penyelidikan geolistrik di Daerah Petak Bahandang adalah sebagai berikut: lapisan akuifer diidentifikasi pada kedalaman 51,89 sampai 95,58 meter; ketebalan lapisan 43,69m; nilai resistivitas batuan 41,3350,37 m; tipe akuifer tertekan dengan lapisan kedap bagian atas kerikil dan lapisan kedap bagian bawah lempung; transmisivitas $0,00126 \mathrm{~m}^{2} /$ det dan debit potensial 0,605 1/det.

Hasil pengukuran geoolistrik di daerah Tumbang Danau dapat dilihat pada Gambar 5. Pembahasan hasil interpretasi pengukuran geolistrik di Daerah Tumbang Danau adalah lapisan akuifer diidentifikasi pada kedalaman 116,39 sampai 173,52meter; ketebalan lapisan 57,13meter; nilai resistivitas batuan 85,85- 103,49 m; tipe akuifer tertekan dengan lapisan kedap bagian atas kerakal dan lapisan kedap bagian bawah granit; transmisivitas $0,00245 \mathrm{~m}^{2} /$ det dan debit potensial $1,1751 /$ det. 


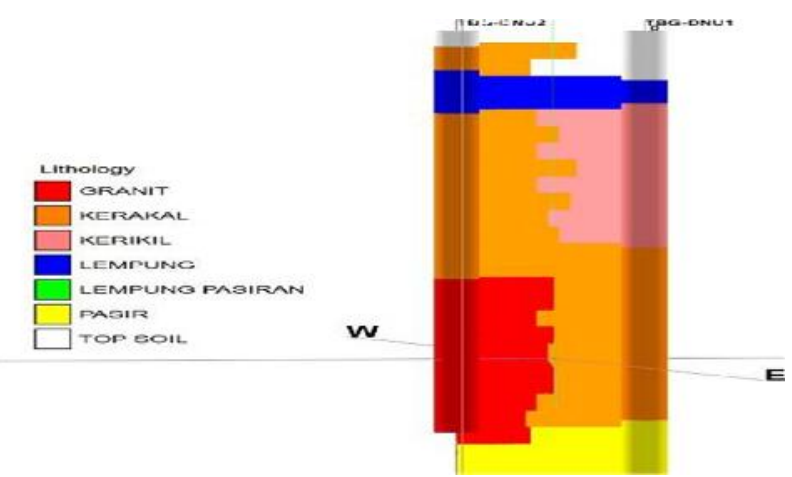

Gambar 5. Hasil interpretasi geolistrik Daerah Tumbang Danau

Hasil pengukuran geolistrik daerah Kampuri dapat dilihat pada Gambar 6.

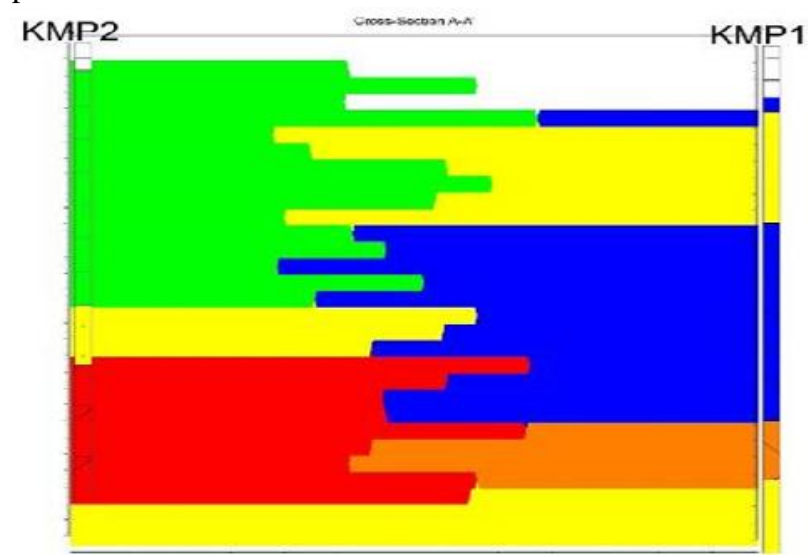

Gambar 6. Hasil Interpretasi geolistrik daerah Kampuri

Pembahasan hasil interpretasi pengukuran geolistrik di daerah Kampuri adalah sebgai berikut lapisan akuifer diidentifikasi pada 2 kedalaman, antara lain:

1. Kedalaman 20,15 sampai 53,89 meter; ketebalan lapisan 3,74 meter; nilai resistivitas batuan 196,54 m; tipe akuifer tertekan dengan lapisan kedap bagian atas lempung dan lapisan kedap bagian bawah lempung; transmisivitas $0,00469 \mathrm{~m}^{2} / \mathrm{det}$ dan debit potensial 2,245 $1 /$ det.

2. Kedalaman 131,96 sampai 166,94 meter; ketebalan lapisan 34,98 meter; nilai resistivitas batuan 82,55 m; tipe akuifer tertekan dengan lapisan kedap bagian atas batuan kerakal dan lapisan kedap bagian bawah batuan granit; transmisivitas $0.00486 \mathrm{~m}^{2} /$ det dan debit potensial $2,3271 /$ det.

Total debit potensial yang dimiliki oleh titik Kampuri 1 sebesar 4,57 L/det. Hasil interpretasi pengukuran geolistrik di daerah Tewai Baru dapat dilihat pada Gambar 7.

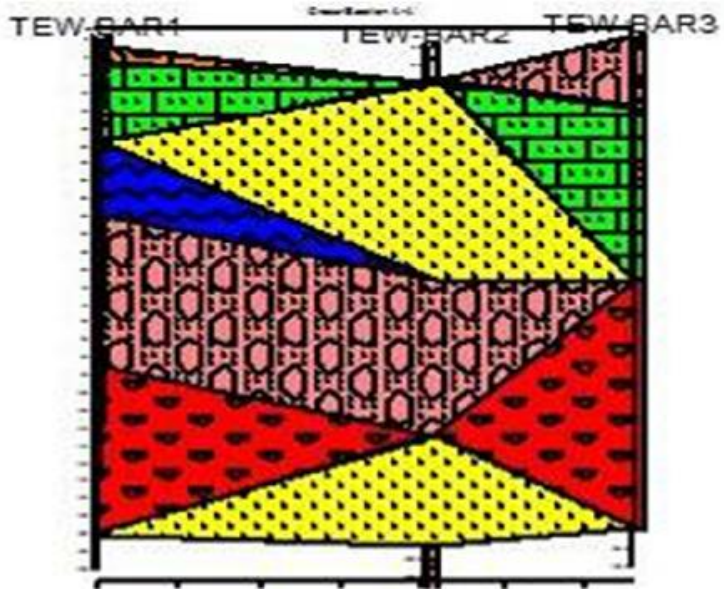

Gambar 7. Hasil Interpretasi Pengukuran Geolistrik di Tewai Baru

Pembahasan hasil intepretasi geolistrik di daerah Tewai Baru adalah sebagai berikut lapisan akuifer diidentifikasi pada 2 kedalaman, antara lain:

1. Kedalaman 9,41 sampai 65,38 meter; ketebalan lapisan 55,97 meter; nilai resistivitas batuan $92,95 \mathrm{~m}$; tipe akuifer dangkal dengan lapisan dangkal bagian atas top soil dan lapisan kedap bagian bawah kerikil; transmisivitas $0,00777 \mathrm{~m}^{2} / \mathrm{det}$ dan debit potensial 3,722 $1 /$ det.

2. Kedalaman 110,30 sampai 141,93 meter; ketebalan lapisan 31,63 meter; nilai resistivitas batuan 90,6 m; tipe akuifer tertekan dengan lapisan kedap bagian atas kerikil dan lapisan kedap bagian bawah kerikil; transmisivitas $0.00439 \mathrm{~m}^{2} /$ det dan debit potensial 2,105 1/det.

Total debit potensial yang dimiliki oleh titik Tewai Baru 2 sebesar 5,82 1/det.

Hasil intepretasi pengukuran geolstrik di daerah Sepang Kota dapat dilihat pada Gambar 8. Pembahasan hasil penyelidikan geolistrik di daerah sepangkota seperti terlihat pada Gambar 8 adalah pada Sepang Kota lapisan akuifer diidentifikasi pada 2 kedalaman, antara lain:

1. Kedalaman 4,47 sampai 46,19 meter; ketebalan lapisan 41,72 meter; nilai resistivitas batuan 185,49 m; tipe akuifer tertekan dengan lapisan kedap bagian atas batuan kerakal dan lapisan kedap bagian bawah lempung; transmisivitas $0,00579 \mathrm{~m}^{2} /$ det dan debit potensial 2,775 $1 /$ det.

2. Kedalaman 56,79 sampai 85,11 meter; ketebalan lapisan 28,32 meter; nilai resistivitas batuan $106,97 \mathrm{~m}$; tipe akuifer tertekan dengan lapisan kedap bagian atas lempung dan lapisan kedap bagian bawah batuan kerakal; 
transmisivitas $0.00393 \mathrm{~m}^{2} / \mathrm{det}$ dan debit potensial 1,885 $1 /$ det.

Total debit potensial yang dimiliki oleh titik Sepang Kota sebesar 4,66 1/det.

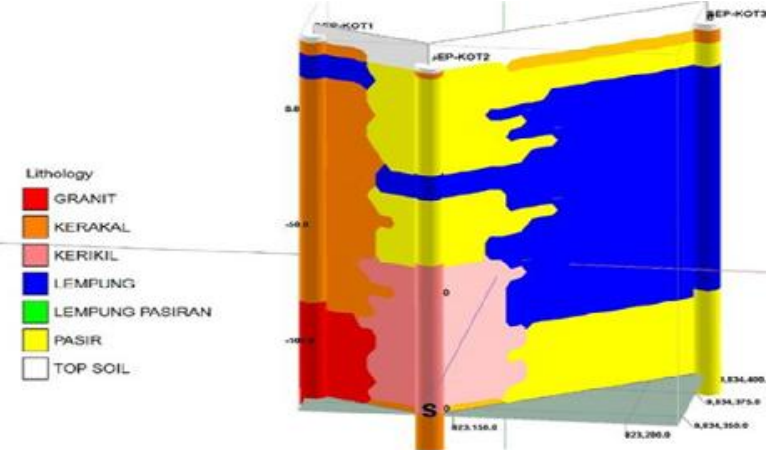

Gambar 8. Hasil Interpretasi Pengukuran Geolistrik Daerah

\section{Simpulan.}

Berdasarkan hasil pemetaan geolistrik, potensi air tanah yang ada adalah sebagai berikut:

1. Daerah Tanjung Riu mempunyai dua akuifer pada kedalaman antara 22,79 m sampai dengan 62,40 $\mathrm{m}$ dan antara kedalaman 92,24 m sampai dengan 137,57 m serta mempunyai potensi debit sebesar 3,27 1/dt.

2. Daerah Petak Bahandang mempunyai lapisan akuifer pada kedalaman 51,89 m sampai dengan 95,58 m serta mempunyai potensi air tanah sebesar 0,605 l/dt.

3. Daerah Tumbang Danau mempunyai aquifer pada kedalaman 116,39 m sampai dengan kedalaman 173,52 m serta mempunyai potensi air tanah sebesar 1,175 1/dt.

4. Daerah Kampuri mempunyai dua aquifer pada kedalaman antara 20,15 m sampai 53,89 $\mathrm{m}$ dan kedalaman antara $131,96 \mathrm{~m}$ sampai dengan $166,94 \mathrm{~m}$ serta mempunyai potensi air tanah sebesar 4,57 1/dt.

5. Daerah Tewei Baru mempunyai dua aquifer pada kedalaman 9,41 m sampai dengan 65,38 $\mathrm{m}$ dan pada kedalaman 110,3 m sampai dengan kedalaman 141,93 m serta mempunyai potensi air tanah sebesar 5,82 1/dt.

6. Daerah Sepang Kota mempunyai dua aquifer pada kedalaman Antara 4,47 m sampai dengan 46,19 m dan pada kedalaman 56,79 sampai dengan kedalaman 85,11 m serta mempunyai potensi air tanah sebesar 4,66 l/dt.

Hasil penelitian diatas dapat dijadikan sebagai potensi air alternatif untuk sebagai alternatif sumber air di Kabupaten Gunung Mas.

\section{Daftar Pustaka}

[1] W. M. Telford, L. P. Geldart, and R. E. Sheriff, Applied Geophysics. Cambridge University Press, 1990.

[2] P. N. Verhoef, Geologi untuk Teknik Sipil. Jakarta: Erlangga.

[3] H. Wahyudi, "Studi Potensi Air Tanah untuk Penanggulangan Bencana Asap di Kabupaten Kapuas," J. Apl. Tek. Sipil, vol. 14, no. 1, pp. 17-30, Feb. 2016.

[4] T. Tatas, M. A. M, S. K. Aziz, and A. Widodo, "Identifikasi Awal Model Akuifer pada Mata Air Umbulan dengan Menggunakan Geolistrik Konfigurasi Schlumberger," J. Apl. Tek. Sipil, vol. 12, no. 1, p. 35, Feb. 2014. 
